\title{
Do Poles flame? Aggressiveness on Polish discussion groups and social networking sites
}

\author{
Anna Tereszkiewicz
}

\begin{abstract}
The analysis encompasses a cross-linguistic comparative study of the phenomenon of online aggression with the aim of analysing the scope of this phenomenon as well as its reflection in the language behaviour of Internet users. In particular the research focuses on the analysis of verbal expression of aggression, hostility and criticism. The study involves content analysis of online media from two different sources: forums and social media. Specifically, the discussion concerns the nature of online aggression in (1) open anonymous forums (2) sign-in forums and (3) social networking media. The study investigates the most frequent instances of impolite, vulgar and aggressive behaviour in these modes of communication online. A further aspect of the analysis concerns the relation between aggression and irony in language.
\end{abstract}

Keywords: Internet, flaming, forums, social networking media, online aggression

\section{Introduction: Aggressiveness online}

Aggression is defined as a general term used to refer to "all activity (physical or verbal), which aims at inflicting physical or psychological injury - real or symbolic. It is usually a reaction to frustration, but also a manifestation of hostility" or "a forceful action especially when intended to dominate" (Paisert 2004: 21-24). The previous research on verbal aggression shows that among the indicators of hostile behaviour, we may identify negative expression of emotions, as well as paralanguage and humour used to display sarcasm and irony. Verbal aggression can be expressed directly, by means of name calling, threatening, or indirectly in the form of gossip or other defamatory activities, as well as in an implied form, which can only be interpreted in a specific situational context (Paisert 2004: 31). 
A lot of research has already been devoted to the phenomenon of online aggressiveness. The Internet is considered a perfect place for venting anger, and expressing aggressiveness and hostility due to its anonymity and openness. Because of the multi-faceted nature of the web and of computer-mediated communication, aggression and vulgarity online may assume different forms, not only verbal, but also visual. The extensive nature of the phenomenon is reflected in the variety of forms of aggression identified so far, i.e., flaming, trolling, spamming, phishing or spoofing. Flaming, the most frequent phenomenon, often treated as a synonym to online aggression, has been said to encompass "aggressive, hostile, profanity-laced interactions" (O'Sullivan \& Flanagin 2003: 70), and "hostile expression of strong emotions and feelings" (Lea et al. 1992: 89), or "verbal aggression, blunt disclosure, and nonconforming behaviour" (Parks \& Floyd 1996: 81).

Many different hypotheses have been put forward as far as the phenomenon of online aggression is concerned and different theories have been developed to account for anti-normative behaviour online. The cues-filtered-out hypothesis, or reduced social cues approach, posits that online communication may trigger aggressive behaviour since it is less personal due to the scarcity of social contextual cues and indicators of social presence (Sproull \& Kiesler 1986). Communication, thus, becomes more uninhibited and more task-focused, but less regulated, and social norms and influences are undermined. As a result, the participants feel less obliged to obey social rules, conventions and standards of politeness. The lack of cues and anonymity reinforce the conviction that there is little need to save the other's face and that there is little risk of sanctions or punishment. This approach sees aggressiveness as a negative effect of the medium (Kim \& Narayan 1991).

The cues-filtered-out hypothesis is associated with the phenomenon of deindividuation. Deindividuation is the term used to account for a different behaviour of individuals in a group. It has been observed that in a group, due to situational features (anonymity, sensory input overload), individuals tend to be less inhibited. In a deindividuated state, namely, self-awareness decreases, which may lead to impulsive, highly responsive, anti-normative behaviour (Christopherson 2007: 3044). As Kiesler et al. (1984) state, communication online tends to resemble deindividuation in a group. Anonymity, lack of personal and social cues affects people's perception of the self and others, as a result of which people are more prone to indulge in anti-social behaviour.

A slightly different explanation is provided by the social identity model of deindividuation effects (SIDE) (Reicher, Spears \& Postmes 1995). According to this model, group affiliation triggers a shift from people's personal to social identity - group membership becomes more salient than our personal aware- 
ness. Social influence and identification with a group requires that we accept specific social norms of this group (Moor et al. 2010: 1537). According to this theory, anti-social behaviour is dependent on social context - aggressive behaviour will take place online if its occurrence belongs to the social norms of a particular group.

The theories focusing on anti-social behaviour range from more technocentric explanations, which state that such behaviour is a consequence of the properties of the medium and contextual features of online communication, to more socially-oriented research, which suggests that such behaviour is determined by social context and group norms.

Yet, although much research has been done into the phenomenon of online aggression, the results of the studies are frequently contradictory. Research comparing computer-mediated and face-to-face communication by Siegel et al. (1986) or Castellá et al. (2000) (see Thurlow et al. 2004: 71) found higher percentages of aggressive verbal behaviour in electronic communication. Yet, Walther (1992) or Spears and Lea (1992) proved that aggressive behaviour is a marginal phenomenon online and the claims about the anti-social nature of computer-mediated communication are exaggerated. Other studies have proved that aggressive behaviour may be more common only in some channels of online communication (Thurlow et al. 2004: 71). In addition, as O'Sullivan and Flanagin (2003) observe, the perception of aggression may be different among the users, and it is subject to change with time, which makes the study of the phenomenon even more difficult.

The differences in the perspectives and approaches to anti-social behaviour online prove the complexity of the phenomenon and show that it defies easy description.

\section{Materials and methods}

The purpose of the following analysis was to examine the forms of verbal aggression and measure the scope of aggressive anti-social practices online among Polish Internet users. The study encompassed three modes of computer-mediated communication: closed and open discussion groups as well as social networking sites. The channels are characterised by different contextual properties which influence the interactional patterns among the users. In open discussion groups, membership is anonymous and not restricted, which affects the relations of social power - the offline power/status differences are minimised. By contrast, in closed groups membership is controlled, the members frequently have to register to the group and reveal their identity, which enhances their identification with 
the group and the observance of group specific standards (Lea et al. 1992; Baym 1993). Similarly, in social networking sites, the identity of the participants is known, as it is a key to establishing interaction and new friendships.

Specifically, the study encompassed the following aims:

- to investigate the indicators of vulgarity and aggressiveness, both verbal and non-verbal;

- to analyse the targets of aggressive behaviour;

- to evaluate and account for the possible differences in the scope of vulgarity and aggression between the analysed modes of communication;

- $\quad$ to account for the reasons underlying aggression and vulgarity.

For the following analysis, posts from two leading Polish open discussion groups were collected - forum.gazeta.pl and dziennik.forum.pl, as well as from two closed groups nakazdytemat.pl and przyjazneforum.pl. The posts were collected over five days from thematically different sections involving politics and social matters in order to examine the influence of the topic of discussion on the level of aggression. As far as the social networking sites are concerned, Facebook was chosen for analysis, as it is nowadays the most popular social platform in Poland. These posts from the supporters of two leading political parties (Civic Platform and Law and Justice) and the most popular social groups were collected too (Kuba Wojewódzki, Demotywatory, Zakaz palenia $)^{1}$. The table below presents detailed numbers of the collected posts:

\begin{tabular}{|l|l|l|}
\hline \multirow{2}{*}{} & Open groups \\
\cline { 2 - 3 } & Politics & Social issues \\
\hline Number of posts & 507 & 482 \\
\hline & Closed groups \\
\hline & Politics & Social issues \\
\hline Number of posts & 568 & 645 \\
\hline & Facebook \\
\hline Number of posts & Politics & Social issues \\
\hline
\end{tabular}

Table 1. Number of posts collected for analysis.

The study was designed to test the following hypotheses:

- there will be a difference between the analysed modes of communication in the scope of aggression and vulgarity;

\footnotetext{
${ }^{1}$ http://nafejsie.pl/2011/04/najpopularniejsze-polskie-fanpage/, last accessed on 18 February 2012.
} 
- contextual features and the topic of discussion will influence the scope of aggression and vulgarity;

- the modes will differ in the nature of aggressive and vulgar behaviour;

- aggression and vulgarity will perform different functions in the analysed modes of communication.

\section{Results and Discussion}

\section{Forms of aggressive and anti-social behaviour}

The analysis of the collected posts allowed the identification of the following forms of aggressive, rude and offensive behaviour:

a) Verbal expression of negative emotions, which encompasses:

- Personal attacks - name calling, insulting, humiliating;

- Argument criticism - negative evaluation of the other's argumentation, ridiculing the other's opinions in vulgar terms;

- General expression of negative emotions and general vulgarity - expression of negative feelings and general opinions, "venting" (Kayany 1998);

b) Non-verbal expression of negative emotions - the use of smileys, emoticons, capitalisation and punctuation to express aggression (cf. Tereszkiewicz 2007).

The most frequent instances of aggressive behaviour encompassed verbal expression of negative emotions in the form of personal attacks - name calling, insulting and humiliating. Aggression was expressed explicitly or in an indirect way by means of irony and sarcasm. The insults are visibly provocative, aim at offending, ridiculing and humiliating another person and involve the questioning of the other's intellect, imputation of stupidity, psychological disorders, or fanaticism (cf. Tereszkiewicz 2007). Insults directed at other participants of the discussion - a specific user, or a group of users - proved the most common. For instance:

Z idiota nie ma sensu dyskutować; porozmawiamy jak skończysz już swoja zaoczna zawodówkę

There's no use talking with an idiot; we'll talk when you finish your weekend vocational school

Zamknij pysk, z psami nie rozmawiam

Shut your trap, I don't talk with dogs 
Za to wystarczy IQ20 żeby gtosować na PiS, więc masz szansę spetnić swój obywatelski obowiąek.

IQ20 is enough to vote for PiS [Law and Justice], so you have a chance to fulfill your civic duty.

Aggression may be also directed at non-participants of the discussions. Specifically, this involves verbal abuse of public figures or social groups:

Ja temu łachmycie nie wierzę nawet tyle co on ma brudu za paznokciamibo jest tachmyta. Profesor od siedmiu boleści, pewno taki sam jak pan LK. I don't believe this dirty scoundrel even a slightest bit; pathetic professor [lit. professor of Seven Sorrows - conventional criticism of a person in Polish, which comes from its religious use: Virgin Mary of Seven Sorrows] with dirty nails, sure the same as LK.

Pisowcy to banda meneli i zjebusów!!

Pis supporters are a gang of dossers/bums and fuckwards!

Such posts express an open and vulgar critique of the individuals involved. Insults of different value and intensity may be observed, ranging from mild insults ("stupid", “idiot"), to words commonly considered vulgar, expressing strongly aggressive content ("scum", "bitch", "fuckward"). In personal attacks directed at other users, the aim is to offend and silence the other person. In this way, insulting replaces argumentation - the users exchange invectives and do not focus on a factual debate.

Personal attacks also take the form of a criticism of arguments provided by other users. The users criticise argumentation, selective use of sources, and superficial knowledge of facts:

Jeśli pozostałe Twoje cytaty są równie rzetelne jak ten, to cały Twój wywód o kant dupy pottuc.

If your other quotations are equally reliable, then you can smash them against the edge of your ass

co za stek idiotycznych bzdur rodem z goebbelsowskiej propagandy what idiotic rubbish straight from Goebbels's propaganda

General expression of negative emotions and general vulgarity, identified in the previous research as "venting" (Kayany 1998), involves the use of rude, offensive and hostile language to express opinions concerning general social or political phenomena, e.g.:

Nic mnie tak nie whurwia jak smród z ryja palacza po tym jak sobie zapali. Rzygać mi się chce na samą myśl o tym. 
There's nothing that pisses me off as the stench from the smoker's mouth after s/he has smoked. I feel like throwing up at the sheer thought about it.

TA OSMIORNICA ZAPUSCILA SWOJE MACKI JUŻ WSZEDZIE. OBLUDA, OSZUKIWANIE POLAKOW, KORUMPOWANIE. KURWA CZAS SIE OBUDZIC!!

THIS OCTOPUS HAS ALREADY SPREAD ITS CLUTCHES EVERYWHERE. HYPOCRISY, CHEATING POLES AND CORRUPTION. FUCK IT'S TIME TO WAKE UP!!

General aggression is not aimed at other users and is usually not related to other posts, but expresses a need the users feel to articulate their personal emotions and frustrations, to let off steam and irritation (cf. Tereszkiewicz 2007). Aggression in this case is directed at venting anger and dissatisfaction concerning political events and social phenomena.

Among all the analysed indicators of anti-social behaviour, personal attacks are the most vulgar and aggressive - personal attacks at other users and at public figures. It is in these areas that the users resort to the most insulting, derogatory and profanity-laced expressions.

The quoted messages show an increased use of capitalisation, punctuation marks and smileys - these are the means which have been developed to make up for the lack of paralinguistic cues in online communication. While in faceto-face communication aggression may also be expressed by means of gesture, mimicry or intonation, in online communication the users need to resort to capitalisation to manifest increased intonation and shouting, and onomatopoeic words or repeated use of punctuation marks to increase the expressiveness of the message (Grzenia 2006; Crystal 2001). The analysed material shows that the users resort to such means in their manifestation of hostile behaviour as well, e.g.:

TAK WLASNIE MYSLALEM...TUSK GO NIE CHCIAL U SIEBIE, WIEC TEN IDIOTA DOSTAL PIANY I ZACZAL KASAC JAK WSCIEKLY PIES..ALE ZALOSNY DUPEK! BUAHAHHACHAHAHH!!!

THAT'S JUST WHAT I THOUGHT...TUSK DIDN'T WANT HIM SO THIS IDIOT FOAMED AT THE MOUTH AND STARTED BITING LIKE A RABID DOG...WHAT A PATHETIC ASSHOLE! BUAHAHHACHAHAHH!!!

Vitalij jebaj katolca!!! Kliczko VITALIJ! VITALIJ! VITALIJ!!!

Vitalij fuck the lousy catholic!!! Kliczko VITALIJ! VITALIJ! VITALIJ!!!

An increased use of punctuation marks and capitalisation, as well as lack of segmentation, reflect a high degree of orality of discourse, emotionality and 
spontaneity. Such discourse properties of the messages prove the focus on affective, not substantial or factual content, and the dominance of the expressive and impressive functions in the messages. The properties clearly prove that the lack of cues and reduced visibility strengthen the emotional style and content of the messages.

Smileys in personal attacks perform different functions - they are used predominantly to weaken the aggressive tone of the message, but paradoxically they may also actually strengthen the force of sarcastic remarks and express a degree of self-complacency of the user (cf. Dresner \& Herring 2010). Smileys are particularly frequent in general commentaries, where they are used to indicate irony. For instance:

Myślatem, że IQ nie może być ujemne, ale przyktad twojego zburzyt to przekonanie $:$ :

I thought that IQ cannot be negative, but yours shattered my belief $(-)$

Więźniowie masowo gtosują na PO [civil platform]. Ci to mają wybitna inteligencję :;

Prisoners vote for PO on a massive scale. They are extremely intelligent indeed :)

However, other forms of smileys or emoticons proved rare, which confirms the previous observations concerning the use of such means of expression by adults in discussion groups (Grzenia 2006).

\section{Scope of aggression}

The study shows that there is a difference in the scope of aggression and forms of aggressive behaviour between the analysed modes of communication; the groups are governed by different sets of norms for behaviour and exhibit varying degrees of antagonisms and vulgarity (see also Laineste 2012). Table 2 presents the frequency of aggressive verbal behaviour in the analysed online media.

The frequency indicates that users tend to exhibit more aggressive behaviour in the mode of communication which provides relative anonymity, which was observed in the previous research as well (Bansal et al. 2011: 23). The analysis proves that it is open groups that are characterised by the highest percentage of aggressive behaviour, both in political and social discussions. This channel of communication dominates as far as the frequency of all the indicators of aggression are concerned. We observe more hostility and personal attacks, more instances of external aggression in particular - aggression in the form of vicious attacks and name calling directed at public figures, both individuals and groups of people. In these cases, the discussion gives way to ad personam 


\begin{tabular}{|c|c|c|c|c|c|c|}
\hline & \multicolumn{2}{|c|}{ Open groups } & \multicolumn{2}{|c|}{ Closed groups } & \multicolumn{2}{|l|}{ Facebook } \\
\hline & Political & Social & Political & Social & Political & Social \\
\hline \multicolumn{7}{|l|}{ Personal attacks } \\
\hline $\begin{array}{l}\text { Attack at another } \\
\text { user }\end{array}$ & $14.9 \%$ & $11.8 \%$ & $1.5 \%$ & $1.8 \%$ & $5.6 \%$ & $0.2 \%$ \\
\hline $\begin{array}{l}3^{\text {rd }} \text { person singular } \\
\text { attack (public figure) }\end{array}$ & $7.4 \%$ & $8.7 \%$ & $0.8 \%$ & $0.3 \%$ & $2.2 \%$ & $0.6 \%$ \\
\hline $\begin{array}{l}3^{\text {rd }} \text { person plural } \\
\text { attack (public } \\
\text { figures) }\end{array}$ & $9.2 \%$ & $2.6 \%$ & $0.7 \%$ & $0.4 \%$ & $4.6 \%$ & $0.4 \%$ \\
\hline $\begin{array}{l}2^{\text {nd }} \text { person singular } \\
\text { attack (public figure) }\end{array}$ & $6.5 \%$ & $1.6 \%$ & 0 & 0 & $0.5 \%$ & 0 \\
\hline $\begin{array}{l}\text { Argument } \\
\text { criticism }\end{array}$ & $11.4 \%$ & $9.5 \%$ & $2.6 \%$ & $3.5 \%$ & $3.1 \%$ & $0.2 \%$ \\
\hline General vulgarity & $8.4 \%$ & $4.3 \%$ & $1.7 \%$ & $0.7 \%$ & $0.6 \%$ & $3 \%$ \\
\hline Flame wars & $1.4 \%$ & 2 & 0 & 0 & 0 & 0 \\
\hline Invectives & 87 & 46 & 5 & 3 & 16 & 15 \\
\hline Swear words & 27 & 25 & 6 & 5 & 14 & 38 \\
\hline Humour & $4.5 \%$ & $3.3 \%$ & $0.5 \%$ & $0.3 \%$ & $3.2 \%$ & $1.3 \%$ \\
\hline $\begin{array}{l}\text { Paralanguage } \\
\text { - Capitalisation and } \\
\text { punctuation } \\
\text { - Emoticons } \\
\end{array}$ & $\begin{array}{l}94 \\
20\end{array}$ & $\begin{array}{l}54 \\
22 \\
\end{array}$ & $\begin{array}{l}17 \\
10\end{array}$ & \begin{tabular}{|l}
14 \\
7
\end{tabular} & $\begin{array}{l}24 \\
19\end{array}$ & $\begin{array}{l}44 \\
33\end{array}$ \\
\hline
\end{tabular}

Table 2. The frequency of aggressive verbal behaviour.

arguments and an exchange of invectives. Aggression is directed against any form of otherness or individuality, and a complete lack of understanding of other political or religious opinions can be seen.

It also in open groups that the so-called flame wars were identified, i.e. is personal attacks which have the form of a prolonged exchange of aggressive messages:

Jesteś żałosny,jak cały PiS i jego zasyfiony $i$ śmierdzacy Jarosław K. >podziwiam twoja mowe mitości mój parzystokopytny kolego.

>to koleżeństwo traktuj jako jednostronne, nie bywam w chlewie skąd nadajesz.

You're pathetic, like PiS and its dirty stinking Jarosław K.

$>$ I admire your love speech my hoofed friend.

$>$ this friendship is only one-sided, I don't visit a pigsty, from where you broadcast.

In a flame war, aggression and insulting become the main aim of interaction, the insults are visibly confrontational, the exchange is not connected with the 
topic of the discussion; rather we may treat it as a peculiar game between the users, a dynamic exchange of attacks and responses, a verbal dueling, where strong offences are the main weapon and the purpose is to win and gain status.

Quite interestingly, the discussions in open groups offer a lot of creativity and play, especially in coining new insults concerning political figures and political affiliations. For example:

pisbojownik ('pisfighter'), pissztuczki ('pistricks'), tuskaszenko ('Tusk+Łukaszenko'), ktamczyński ('lieczyński'), POmatot ('POidiot'), tuskoland, polszewia ('Polshevik country'), pislamowcy ('pislam')

The insults - vivid, expressive and rich in meaning - prove a considerable degree of inventiveness of the users, their wish to stand out, attract attention and provoke by using uncommon insults.

What distinguishes this mode of communication is the presence of a small but significant number of insults directed at public figures expressed in the $2^{\text {nd }}$ person singular form - you. This form of address gives the illusion of a more direct, closer contact with the addressee, e.g.:

Rybiński masz problemy ze swoją osoba, gnębi cię stres czy żona ci się puszcza?

Rybiński do you have problems with yourself, are you stressed or your wife cheats on you?

\section{DONALD ZAMKNIJ MORDE DONALD SHUT UP}

Generally, we may observe that the users participating in open groups do not focus on a discussion per se, but rather on venting feelings, frustrations and strong opinions. The purpose of aggression and vulgarity is to let off steam and to provoke. These purposes are reflected in the messages comprising plain vulgarity expressed without reference to the content of the other users' statements. Such posts assume the form of one-liners (Vrooman 2002: 61), i.e. short, single-line offensive and highly expressive statements with a message meant to criticise, crush or silence the opponent. A higher percentage of interpersonal attacks in open groups may result from the lack of closer relations among the participants of the discussion. As Castells observes (2003: 150), the physical, spatial and temporal distance facilitates the expression of personal opinions, as radical and offensive as they may be.

Anonymity also influences the style and content of the messages, which become more emotional and expressive (Derks et al. 2008). Open groups resort most frequently to capitalisation and increased punctuation to express paralinguistic content. Due to the openness of the groups and a large number 
of the participants, the users feel the need to make themselves more conspicuous, more visible among others. A message with increased capitalisation and punctuation, though less legible, is definitely more prominent and noticeable.

As far as closed groups are concerned, we may observe a definitely lower number of hostile personal attacks. The forms of aggression identified in these groups encompass criticism of argumentation and few instances of name calling. The messages show that the focus in these groups is on an exchange of opinions. The users try to understand the perspective of other participants and reach a consensus. Vulgarity and aggressiveness are definitely perceived as a violation of the norm. The users are advised to pay more attention to the use of normative language and to avoid vulgarity, e.g.:

Remik hamuj się z takimi stowami, ok?

Remik, restrain yourself with such words, ok?

XY-Dominiku, nie w ten sposób ... rozumiem ze Jarek cie wku*wia, mnie również. Ale tego typu komentarze to może być tylko woda na miyn dla troli. Dominik, not in this way ...I understand that Jarek pisses you off, me too. But such comments only feed the trolls.

The percentage of anti-social behaviour in closed groups confirms the claims emphasising the influence of group norms on the behavioural standards of the participants. Lower percentage of aggression in closed groups may signify observation of the netiquette - i.e. the rules which outline behavioural standards within the group.

Interesting differences in anti-normative behaviour between political and social groups on Facebook may be observed. In political discussions, attacks at other participants of the discussion and at public figures proved the most frequent. In contrast to the open groups, the attacks have a milder form or are expressed in a more indirect way. Moreover, a significant percentage of irony and sarcasm was identified, which can be seen in the following exchanges of opinions, e.g.:

Pawle, czytając Twój komentarz odniostem wrażenie, że defekt to ma tu ktoś inny.

Paweł, reading your comment I had a feeling that it is someone else that has a defect here.

A. Ewa Fajer - mój syn idzie po raz pierwszy gtosować i to na PO, myśle, że na koszulkę zastugujemy (:)

B. Idzi Czarnecki - Pani Ewo, wydaj mi się, że brakuje w Pani nazwisku jednej literki. 
A. Ewa Fajer (Suker) - my son will be voting for the first time, and for PO; I think we deserve a T-shirt :)

B. Idzi Czarnecki - Ewa, I think one letter is missing in your surname.

A. poza tym dla Premiera Tuska zawsze znajde czas (-)

B. ja zawsze znajdę dla Niego nie tylko czas, ale również jajka i pomidory.

A. I will always have time for the Prime Minister :)

B. I will have for him not only time but also eggs and tomatoes.

In these instances, the users manage to clearly express their opinions by a sarcastic play on the name of the opponent or by referring to previous statements of other users, which exemplifies the use of wit and irony to convey insults or milder forms of ridicule.

Anti-normative behaviour and the insults directed at the opponents in political groups clearly function as group-integrating devices, aiming at ridiculing and humiliating the supporters of other political parties. Aggression is a means to express one's identity and particular political affiliation. A clear division into 'us' and 'them' can be seen, which leads to polarisation - the opinions of both supporters and opponents of particular views become more intensified, with more restrained, moderate views fading into the background.

As far as social groups are concerned, it is general vulgarity that prevails in the messages. There is a definitely smaller percentage of interpersonal aggressiveness. General vulgarity, however, has a slightly different overtone in this context and is not perceived as anti-social or negative. Quite the contrary, it seems to constitute a social norm, a custom. It is not an expression of personal frustrations, as was the case with open groups. Rather, vulgarity and profanity are a form of entertainment, the users indulge in crudeness in order to show off and to have fun, e.g.:

Szkoda że ci nie wpierdolit.

Zajebałem mu dwa kopy i uciekt $\odot$ jak mysz spierdolil jak karaluch Jeżeli jakiś mottoch ci wtazi na środek to się mówi: Wypierdalaj staruchu;D Te jebane kostko to gowno, $w$ Polsce wszedzie to jest a po tym się chujowo na desce jezdzi, powinni plyty betonowe zajebac $i$ by byto git, komuna jebana :] It's a pity he didn't beat the shit out of you.

I fucked him two kicks and he run away :) he fucked off like a mouse, like a cockroach

If such mob blocks your way you say: get the fuck out of here old man;D These fucking cobbles is a shit, in Poland it is everywhere and it's fucking awful for skateboarding, they should fucking steal flagstones and it would be good, a fucking commune :] 
A to skurwiele sobie reklamę zrobity, psia ich mać

Przejebane :D

Mnie wkruwia cena fajek :D

Ja mam na to wyjeb ... i pale $i$ nie pale

Those motherfuckers have made themselves a good ad, fuck them/gorblimey

Fucked up :D

The price of fags pisses me off :D

I give it a fuck ... I smoke and I don't smoke

We see the affirmation of freedom of expression, lack of restrictions, spontaneity, affirmation of vulgarity and profanity. The participants stick to specific communicative and behavioural norms, which is reflected in repetitive rhetorical patterns that can be observed in the messages. The users seem to follow a specific behavioural trend, which strengthens their integration with the other users.

\section{Conclusions}

The analysis shows that there is aggressiveness among Polish users of the Internet, yet it is not as widespread as we could assume, or as is widely assumed. We agree with Luzón (2011) that aggressive behaviour can be placed along a continuum - ranging from mild rebukes to vulgar offences. Moreover, aggressiveness online does not have the same purpose as offline aggression. Its purpose is not only to humiliate, hurt and offend another person, or to vent negative energy and anger or frustration. Its role is to mark authority, to create and maintain identity, but also to perform, to enter into a verbal game, to entertain oneself and others by indulging in vulgarity and insults. The messages with aggressive content in general do not have much informative value, but predominantly fulfill expressive and impressive functions.

The conclusion which can be drawn is that aggression is not always perceived as negative and anti-social, and that certain forms of aggressiveness have become acceptable online (cf. O'Sullivan \& Flanagin 2003). The scope of aggressive behaviour may result from an interplay of a few factors, associated with different contextual and technological variables:

- In open groups - aggressiveness results from anonymity and lack of social and personal cues, the perception of the forum as a place for expressing opinions; aggression and vulgarity are a means of establishing authority and proving one's confidence; low social presence facilitates the expression of negative emotions; weak bonds with other participants decrease the awareness of the feelings of other users and of the effects of aggression; 
- In closed groups - a low percentage of anti-social behaviour proves the influence of group norms on the behavioural standards of the participants (Lea et al. 1992; Baym 1993); low frequency of aggression results from a stronger affiliation to the group, fear from being excluded from the group, feelings of commonality, shared interests and norms, which is associated with the purpose of this mode of communication, i.e., to maintain social contacts;

- In politically-oriented social networking groups - anti-normative behaviour results from the need to express one's authority, identity and political affiliations; supporters of a particular political party feel the need to consolidate their allegiance to a specific group, which is expressed by their hostility towards the opponents;

- In socially-oriented groups on Facebook - in this context, vulgarity is perceived as a norm, a means of socialising; a degree of playfulness in aggression and vulgarity can be observed; aggressiveness results from the participants' focus on the maintenance of interpersonal relations, the need for group inclusion; the participants stick to particular communicative patterns and behavioural standards in the group;

- The scope of aggressiveness clearly depends on the topic of discussion - uncivil behavior and ad personam attacks are widespread especially in political groups; vulgar language serves as a device consolidating the group, strengthening the affiliation to a specific group and is a marker of a strong rejection of the others' views.

The differences in the level of aggression prove that the phenomenon cannot be seen as merely a negative effect of the medium and its properties. It can be said that it is both reduced cues, the social context and group norms that influence the scope of aggression online. Anonymity, as well as the lack of moderation, and hence, lack of any risk for immediate sanctions allow the participants to indulge in aggression and to be more expressive (Derks et al. 2008). The research also confirms the previous observations that social and cultural context factors influence the behaviour of the participants. The users transfer political and social problems and conflicts to online reality (Kayany 1998: 1137). The study shows that it is the political context that particularly affects communication the animosity between the two leading political parties in Poland is strong in offline contexts as well.

Yet, it seems that sheer anonymity and reduction of cues and social context is not enough for the explanation of the phenomenon. Anti-social behaviour is often triggered by personal wishes to stand out, to attract attention by means of aggressive rhetoric. Being more challenging, provocative, creative and insult- 
ing is a strategy to become more visible, to stamp one's authority and create an online identity. In this way, aggression may be understood in Bell's terms as "the most virulent contest on-line", the creation, maintenance, and performance of identity (Plotz \& Bell 1996: 183).

Aggression online has many different faces, takes different shapes and may have different consequences depending on the context. Moreover, as mentioned above, users' attitudes towards anti-social behaviour online differ, ranging from disapproval, ignorance to a more positive perception of aggression as a form of entertainment (Moor et al. 2010: 1542). All these factors enhance the complexity of the phenomenon and make any easy generalisation and evaluation difficult.

\section{References}

Bansal, Ankush \& Sharma, Siddharta \& Kumar, Kapil \& Aggarwal, Anuj \& Goyal, Sheenu \& Choudhary, Kanika \& Chawla, Kunal \& Jain, Kunal \& Bhasin, Manav 2011. Classification of flames in computer mediated communication. International Journal of Computer Applications, Vol. 14, No. 6, pp. 21-26.

Baym, Nancy 1993. Interpreting soap operas and creating community: Inside a computermediated fan culture. Journal of Folklore Research, Vol. 20, No. 2-3, pp. 143-176.

Orengo Castellá, Virginia \& Zornoza Abad, Ana M. \& Prieto Alonso, F. \& Peiró Silla, José María 2000. The influence of familiarity among group members, group atmosphere and assertiveness on uninhibited behavior through three different communication media. Computers in Human Behavior, Vol. 16, No. 2, pp. 141-159.

Castells, Manuel 2003. The rise of network society. Malden: Blackwell.

Crystal, David 2001. Language and the Internet. Cambridge: CUP.

Christopherson, Kimberly M. 2007. The positive and negative implications of anonymity in Internet social interactions: 'On the Internet, Nobody Knows You're a Dog'. Computers in Human Behavior 23, pp. 3038-3056.

Derks, Daantje \& Fischer, Agneta \& Bos, Arjan 2008. The role of emotion in computermediated communication: A review. Computers in Human Behavior 24, pp. 766-785.

Dresner Eli \& Herring, Susan 2010. Functions of the nonverbal in CMC. Emoticons and illocutionary force. Communication Theory 20, pp. 249-268.

Grzenia, Jan 2006. Komunikacja językowa w internecie. [Linguistic communication on the Internet.] Warszawa: WN PWN.

Kayany, Joseph 1998. Contexts of uninhibited online behavior: Flaming in social newsgroups on Usenet. Journal of the American Society for Information Science, Vol. 49 No.12, pp. 1135-1141.

Kiesler, Sara \& Siegel, Jane \& McGuire, Timothy 1984. Social psychological aspects of computer-mediated communication. American Psychologist 39, pp. 1123-1134.

Kim, Min-Sun \& Narayan, Raja 1991. Verbal aggression and self- disclosure on computer bulletin boards. Paper presented at the Annual Meeting of the International Communi- 
cation Association, Chicago, IL, May. ED334 620. http://eric.ed.gov/PDFS/ED334620. pdf, last accessed in June 2011.

Laineste, Liisi 2012. Verbal expressions of aggressiveness on the Estonian Internet. In: L. Laineste \& D. Brzozowska \& W. Chłopicki (eds.) Estonia and Poland. Creativity and tradition in cultural communication, Vol 1. Tartu: ELM Scholarly Press, pp. 205-220.

Lea, Martin \& O'Shea, Tim \& Fung, Pat \& Spears, Russell 1992. Flaming in computer mediated communication: observations, explanations, implications. In: M. Lea (ed.) Contexts of Computer Mediated Communication. New York: Harvester Wheatsheaf, pp. 89-112.

Luzón, María José 2011. 'Interesting post, but I disagree': Social presence and antisocial behaviour in academic webblogs. Applied Linguistics, Vol. 32, No. 5, pp. 517-540.

Moor, Peter \& Heuvelman, Ard \& Verleur, Ria 2010. Flaming on YouTube. Computers in Human Behavior 26, pp. 1536-1546.

O’Sullivan, Patrick \& Flanagin, Andrew 2003. Reconceptualizing 'flaming' and other problematic communication. New Media and Society, Vol. 5, No. 1, pp. 67-93.

Parks, Malcolm \& Floyd, Kory 1996. Making friends in cyberspace. Journal of Communication, Vol. 46, No. 1, pp. 80-97.

Peisert, Maria 2004. Formy i funkcje agresji werbalnej. Próba typologii. [Forms and functions of verbal aggression. A typology.] Wrocław: WUWr.

Plotz, Trudy \& Bell, Elizabeth 1996. Invisible rendezvous: Mapping the music and community of computer-mediated communication through performance (Point and counterpoint). Text and Performance Quarterly, Vol. 16, No. 1, pp. 172-188.

Reicher, Steve \& Spears, Russell \& Postmes, Tom 1995. A social identity model of deindividuation phenomena. In: W. Stroebe \& M. Hewstone (eds.) European review of social psychology, Vol. 6. Chichester: Wiley, pp. 161-198.

Siegel, Jane \& Dubrovsky, Vitaly \& Kiesler, Sara \& McGuire T. 1986. Group processes in computer-mediated communication. Organizational Behavior and Human Decision Processes 37, pp. 157-187.

Spears, Russel \& Lea, Martin 1992. Social influence and the influence of the social in computer-mediated communication. In: M. Lea (ed.) Contexts of Computer Mediated Communication, London: Harvester Wheatsheaf, pp. 30-65.

Sproull, Lee \& Kiesler, Sara 1986. Reducing social context cues: electronic mail in organization communication. Management Science 32, pp. 1492-1512.

Tereszkiewicz, Anna 2007. Flaming over the borders - aggressiveness on the Internet. Prace naukowo-dydaktyczne Państwowej Wyższej Szkoły Zawodowej w Krośnie 27, pp. 171-181.

Thurlow, Crispin \& Lengel, Laura \& Tomic, Alice 2004. Computer mediated communication. Social interaction and the Internet. London: Sage.

Vrooman, Steven 2002. The art of invective. Performing identity in cyberspace. New Media and Society, Vol. 4, No. 1, pp. 51-70.

Walther, Joseph 1992. Interpersonal effects in computer-mediated interaction: a relational perspective. Communication Research 19, pp. 52-90. 